\title{
J.J.Rushchitsky \\ ON SOME MILE-STONES IN SCIENTIFIC LIFE OF PROFESSOR ALEXANDER N. GUZ
}

\author{
S.P.Timoshenko Institute of Mechanics, Nesterov str. 3, 03680, Kyiv, Ukraine \\ e-mail:rushch@inmech.kiev.ua
}

\begin{abstract}
The article is prepared in occasion of awarding Professor A.N. Guz the ICCES Medal for Life-Time Achievements and corresponds to the lecture at the symposium to honor of A.N. Guz within the framework of ICCESS-12 (International Conference on Computational and Experimental Engineering and Sciences, Greece, Crete, April 30 - May 4 , 2012). Four important mile-stones in scientific life of A.N. Guz are shown and discussed: the defence of doctor of sciences dissertation; the forming new scientific directions and scientific school; the directorship at SP Timoshenko Institute of Mechanics; the preparation of many monographs, which can be classified as the first ones in the world scientific literature.
\end{abstract}

Keywords: Professor A.N. Guz; ICCES Medal for Life-Time Achievements; scientific life; some mile-stones.

Professor Doctor of Sciences Alexander N.GUZ is Director of the Institute of Mechanics of the National Academy of Sciences of Ukraine from 1976 until present. The institute is located at city Kyiv - capital of Ukraine.

Consider first some important facts from the bio.

$\triangle$ PERSONAL DATA: Born in Ukraine, January 29, 1939; Nationality: Ukrainian; Citizenship: Ukraine.

\ ACADEMIC DEGREES: 1956-1961, Kiev University, Mechanics (Diploma with Distinction); 1962, Candidate of Sciences (PhD), Institute of Mechanics (in the age 23 years); 1965, Doctor of Sciences (the second doctorate degree), Institute of Mechanics (in the age 26 years); 1969, Full Professor, Institute of Mechanics.

A EMPLOYMENT: 1960-1967, Engineer, Post-graduate Student, Senior Scientist, Institute of Mechanics; 1967 -

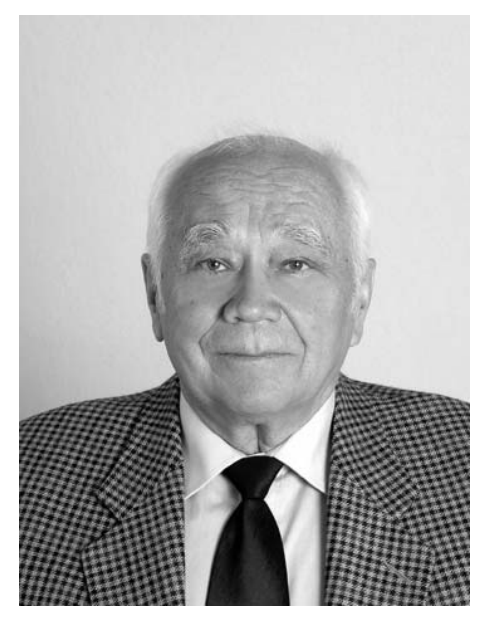
present, Head of the Department of Dynamics and Stability of Continuum Media, Institute of Mechanics; 1976 - present, Director of the SP Timoshenko Institute of Mechanics.

$\triangle$ PUBLICATIONS: 62 monographs (including 15 solo) and about 900 scientific papers (including 400 solo).

Эта публикация соответствует докладу автора на посвященном Гузю А.Н. симпозиуме “Линейные и нелинейные проблемы механики твердого тела, механики разрушения и родственных проблем " в рамках международной научной конференции ICCESS-12 (Греция, Крит, 30 апреля - 4 мая, 2012) в связи с награждением Гузя А.Н. медалью ICCESS-12 за достижения в продолжение жизни. 
$\triangle$ ADVANCED TEACHING ACTIVITIES: Supervisor of 35 Doctor of Sciences theses (the second doctorate degree) and about 100 Candidate of Sciences (PhD) theses.

$\triangle$ MEMBERSHIPS (ACADEMIES): 1978, Member of the National Academy of Sciences of Ukraine; 1992, Member of the Academia Europaea; 2001, Fellow of the World Innovation Foundation; 2002, Member of the European Academy of Sciences.

$\Delta$ AWARDS (PRIZES): 2007 Blaise Pascal Medal of the European Academy of Sciences; 1985, State Prize of USSR; 1967, Lenin Komsomol Prize for Young Scientists; 1979, 1988, State Prize of Ukraine; 1973, Lenin Komsomol of Ukraine Prize for Young Scientists; 1979, 1983, 2000, Prize of the National Academy of Sciences of Ukraine.

$\triangle A D D I T I O N A L$ INFORMATION (PUBLICATIONS): The multi-volume collective fundamental books were supervised and co-authored by Prof. A.N. Guz:

Methods for Shells Theory in five volumes $(1980-82) ; \quad$ Mechanics of Composite Materials and Structural Members in three volumes (1982 - 83); Three-Dimensional Problems of the Theory of Elasticity and Plasticity in six volumes (1984-86); Mechanics of Coupled Fields in Structural Members in five volumes (1987 - 89); Nonclassical Problems of Fracture Mechanics in four volumes (1990 - 94); Mechanics of Composites in twelve volumes (1993 - 2003).

Actually the multi-volume collective book "Advances of Mechanics" in six volumes (Editor-in-Chief A.N. Guz) was published in 2005 - 2011. Some main scientific results of A.N. Guz were presented (in English) in the book series "Classics of World Science", vol.11, "Olexander M Guz" (TIMPANI, 2006, 521 p.).
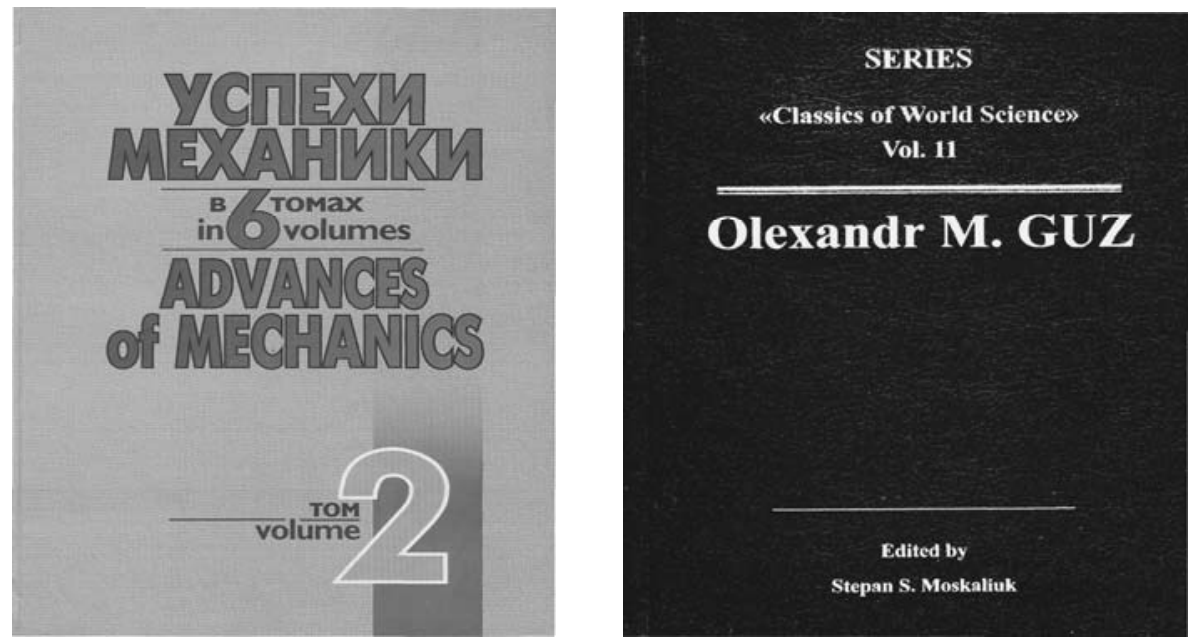

On the next page the map of Ukraine is shown as the homeland of A.N. Guz.

It seems to be worthy to note that the author had a possibility to observe many years the Ukrainian science and the scientific career of Professor A.N. Guz - the prominent Ukrainian scientist with the world recognition.

While someone being met a gifted and very successful man and being communicated with the man further, then very often after some time he is asking himself a question - how it is possible to reach such a success under seemingly so unfavourable conditions?

Of course, the deciding factor is the talent. But sometimes the conditions are looking not so unfavourable, when being considered more thoroughly. tors -

These additional conditions of success in science are formed by three as if objective fac-

the state of school education,

the state of university education,

the organization of scientific life in the country. 


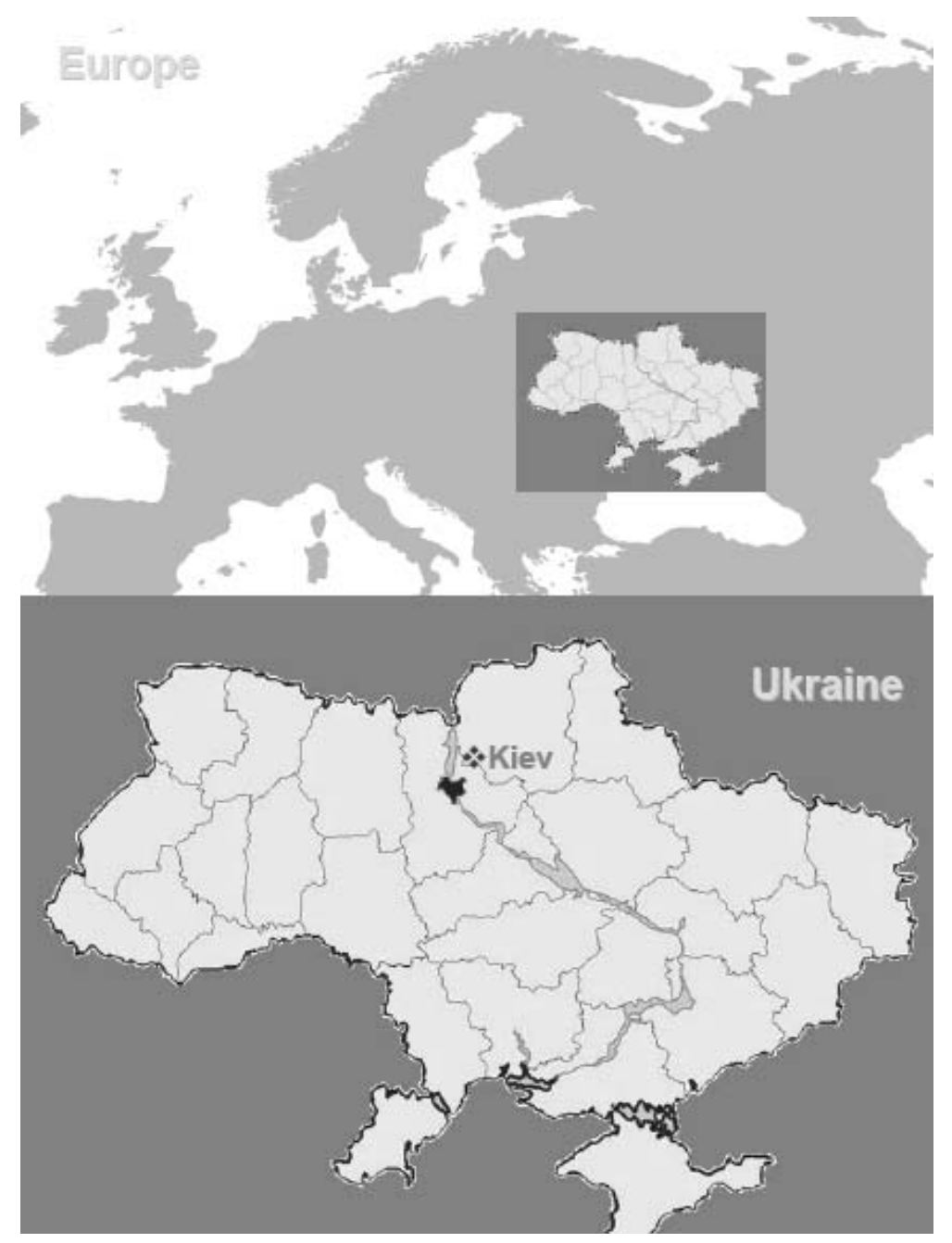

In each country, these factors are defined by contributions of many generations of people, who were working to develop the education and science. In area of mechanics - to which the Guz's main achievements are belonging - first of all, Professor S.P.Timoshenko should be mentioned.

A few words about these factors as applied to Kyiv and Chernigov regions of Ukraine, where the Guz's personality was formed. This part of Ukraine for many centuries has been belonged first to the Russian Empire and then to the Soviet Union, in many attributes the em-pire too

The Russian Empire has been developed the science mainly by relations with Europe:

by invitation of prominent European scientists to work in Russian Empire (for example, Leonard Euler has been worked about 25 years in the Petersburg Emperor Academy of Sciences);

by sending the talented emperor nationals to Europe for education and scientific work (for example, the Ukrainians Ostrogradsky (the Gauss-Ostrogradsky theorem) and Buniakovsky (Buniakovsky inequality) were started in Europe and then were working in Petersburg as members of Academy). By this scheme, mechanicians V.L. Kirpichov, S.P. Timoshenko, A.N. Dinnik have been formed as the outstanding scientists and organizers of education and science. 
The third factor is associated with the imperial ambitions of Soviet Union and its development of military-industrial complex. This complex needed the constant afflux of fresh scientific and technological ideas. All who shows the interest to the science, was recruited to the science. This big mass of people included many talented scientists who were working in the quite favourable conditions.

Starting with 50 -ies of XX century in the area of mechanics, the scientific congresses, conferences, symposiums and schools have been organized, where practically all the working in the country mechanicians have been gathered. Each of such actions has its own specificity.

For example, the schools were organized at resorts, the leading scientists were invited to lecture and young scientists participated very gladly. During one year, up to ten actions have been organized, but the country has been given money and young scientists could participate at all the conferences and schools. This formed a climate of creative work and concurrence. Just in such a climate has been occurred the scientific career of Alexander Guz.

The first mile-stone can be fixed as the Doctor of Sciences Thesis defence (1965) by the extremely young Alexander Guz (26 years old).

He has been made the Candidate Thesis (the first doctorate degree - Doctor of Philosophy) during one year after finishing the university and the Doctor Thesis in static stress concentration in shells (the second doctorate degree - Doctor of Sciences) in the age of 26 years.

At that time, he was the youngest Doctor of Sciences in the Soviet Union.

The defence of A.N. Guz's doctor thesis was the great event in the scientific life of Kiev's mechanicians. Many prominent scientists of the former USSR supported his doctor thesis: Professor A.I. Lurie (Leningrad), Professor N.H. Mushtary (Kazan), Professor Kh.A. Rakhmatullin (Moscow), etc. The scientific council giving the Doctor of Sciences degree in mechanics includes all the best working in Kiev mechanicians.

They established a fact of the birth of new potent figure in Ukrainian mechanics.

That was the second case in the history of the Institute of Mechanics of doctor thesis defence by very young scientist.

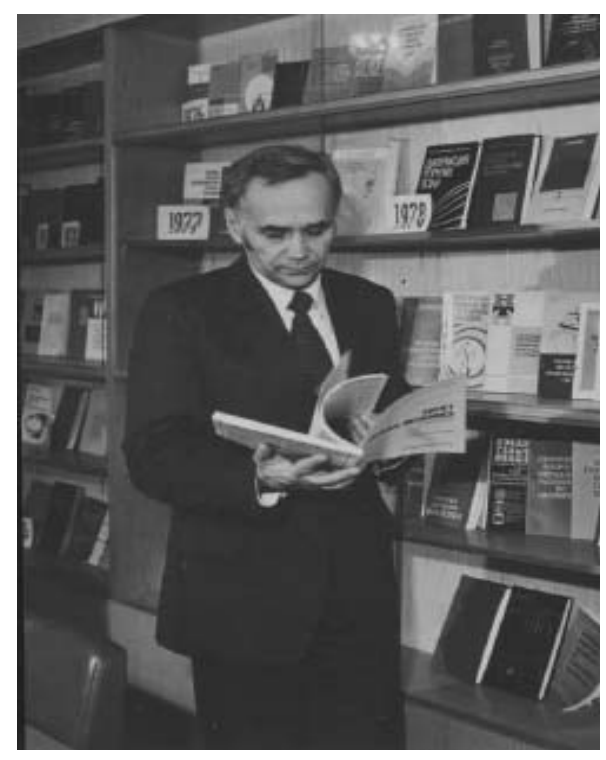

Figure 1: Young Guz in the institute library.

The first case was created by the world-known mechanician and physicist academician N.N. Bogolyubov, who many years worked at Institute of Mechanics in Kyiv and published world-known results in non linear mechanics being in the staff of this institute. 

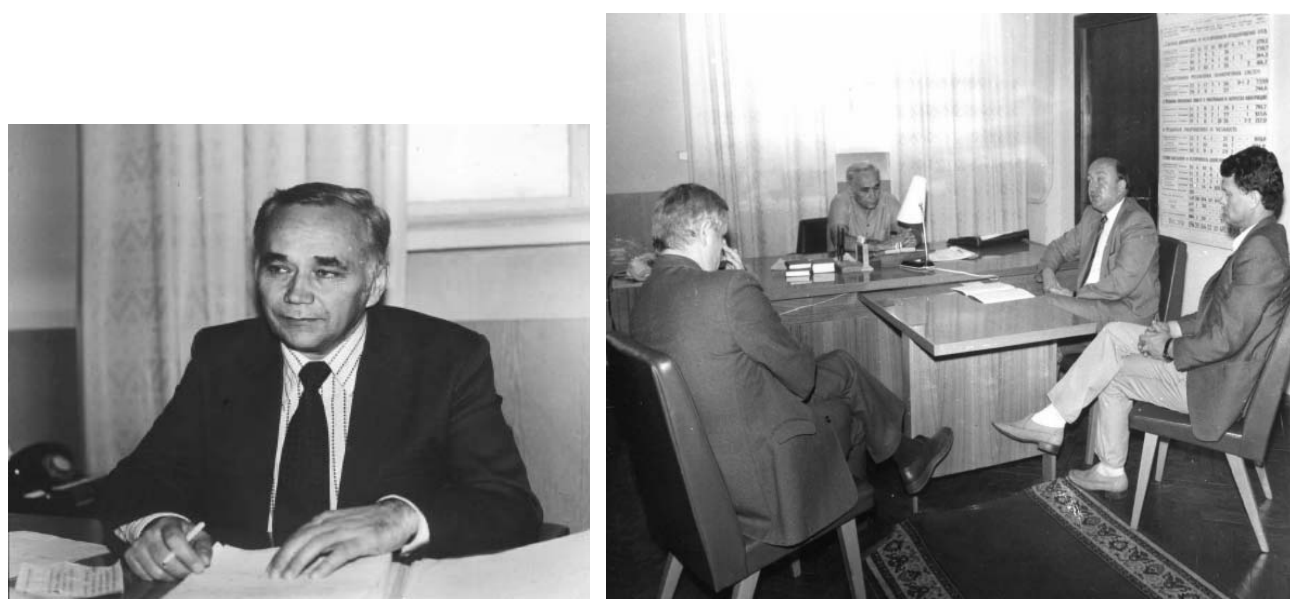

Figure 2: Young Guz as Head of Department. Figure 3: Young Guz in the director office.

The second mile-stone can be meant as organization (1967) the new Department at the Institute of Me chanics with A.N. Guz as Head of Department and then owing the scientific activity of A.N. Guz quick obtaining the new results in mechanics, what was resulted in preparing the monographs and creating the scientific school.

By the way, at present the Guz's scientific school includes 36 Doctors of Sciences and 100 Candidates of Sciences (Doctors of Philosophy).

The small part of them are participating in this symposium - Professor Akbarov from Turkey, Professor Zozulya from Mexico, Professor Guz Junior from the United Kingdom, Professors Bogdanov, Nazarenko, Chekhov Val., Chekhov Vic., Tkachenko from Ukraine.

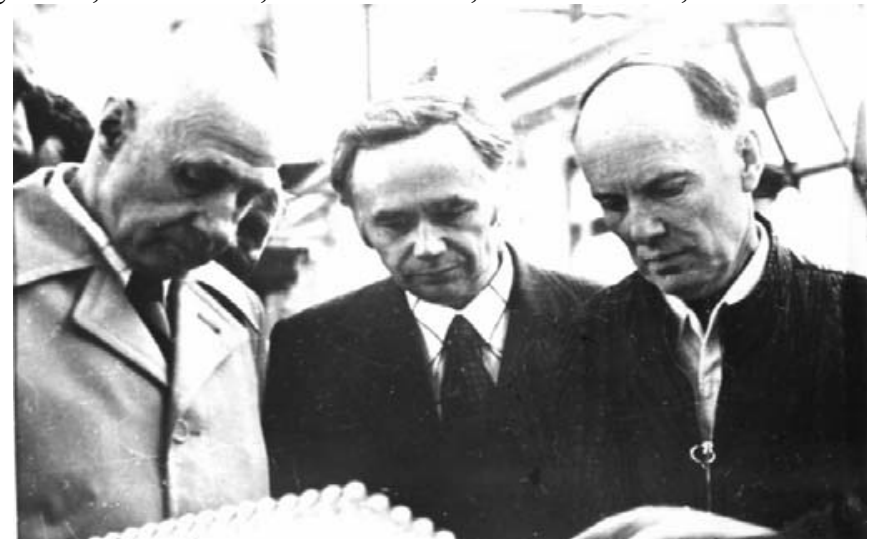

Figure 4: Director of Institute Guz with President of Academy Paton and Academician-Secretary Mitropolsky.

The third mile-stone (1976) is meant as the confirmation to a post of Director of the Institute of Mecha nics in Kiev. It is necessary to note that last 36 years A.N. Guz holds the Director of Institute of Mechanics of the National Academy of Sciences of Ukraine.

That is noted in the beginning of the lecture. But it is not wide known that the Institute was the greatest institute in solid mechanics in the USSR in 1980 - about 1500 employees including 60 Doctors of Sciences and 150 Candidates of Sciences working mainly in solid mechanics.

It seems, this institution in mechanics is until now the greatest one in Europe and possibly in the world too.

Besides that it cannot be omitted the fact that Professor S.P.Timoshenko was the founder and the first Director of the Institute of Mechanics from 1918 to 1921. 


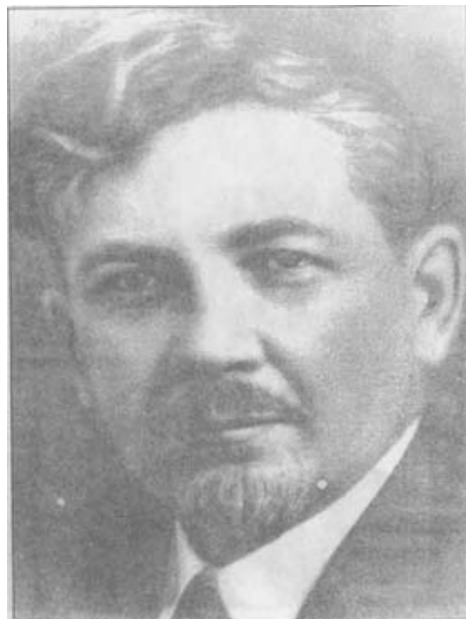

From 1997 the Institute of Mechanics is named after S.P. Timoshenko.

I permit myself to express my hope that Professor S.P. Timoshenko is not forgotten in the world engineering community.

It was clearly coming to light on this stage of scientific activity of A.N. Guz, that he is a good organizer of science and in all A.N. Guz is very fruitful man in science.

In writing the books he follows the rule of the novelty, that is, he is writing mainly the scientific monographs, most part of each consists of the new scientific results of author.

His scientific contribution into mechanics is commensurable with contributions of many scientific institutions with many collaborators (here I ought to repeat the data from $\mathrm{CV}$ - he is the author or co-author of 62 books and more than 900 scientific papers).

This fact can be estimated for Ukraine and may be for Europe also as the unique phenomenon of the nature.

May be one more peculiarity of A.N. Guz's scientific activity is also worthy to mention - he is writing all his solo books and articles without assistance. In the case of common publications the significant part of this work is done by A.N. Guz individually and next parts are initiated and discussed by A.N. Guz.

The fourth mile-stone (1992) is associated with the international activity of Professor A.N. Guz, starting with election to two European academies - Academia Europaea in London (1992) and European Academy of Sciences in Brussels (2002) as well as the membership in the General Assembly of the International Union of Theoretical and Applied Mechanics (IUTAM).

Finally a few words about books of Professor A.N. Guz from the list of 62 books.

Thirteen of them are the first books in world scientific literature (the number before the title of the book means the number in the full list of monographs of Professor A.N. Guz):

three books on three-dimensional theory of stability of deformable bodies

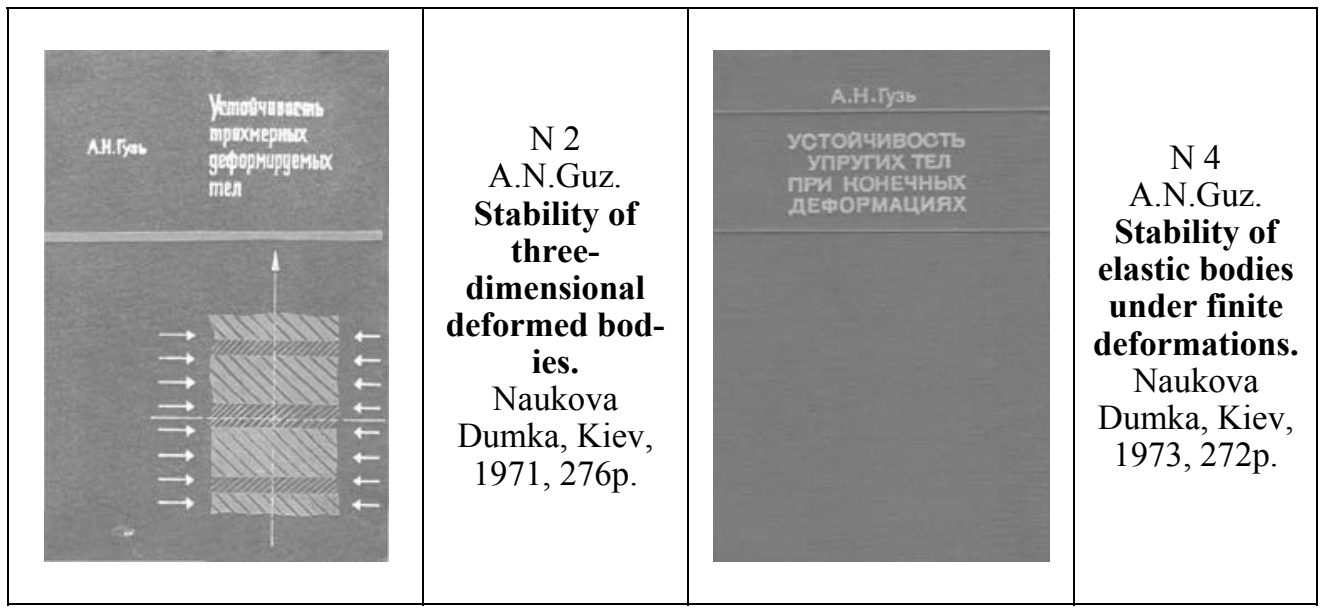




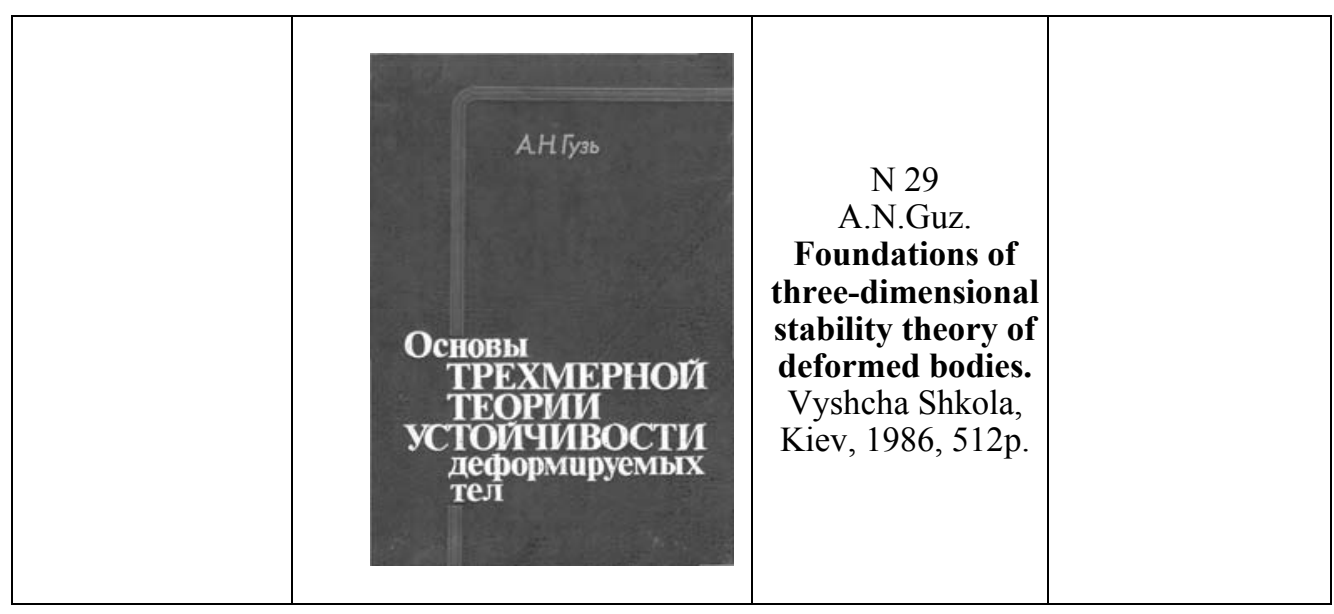

one book on mechanics of nanocomposites one published solo book on local stability loss near mine workings

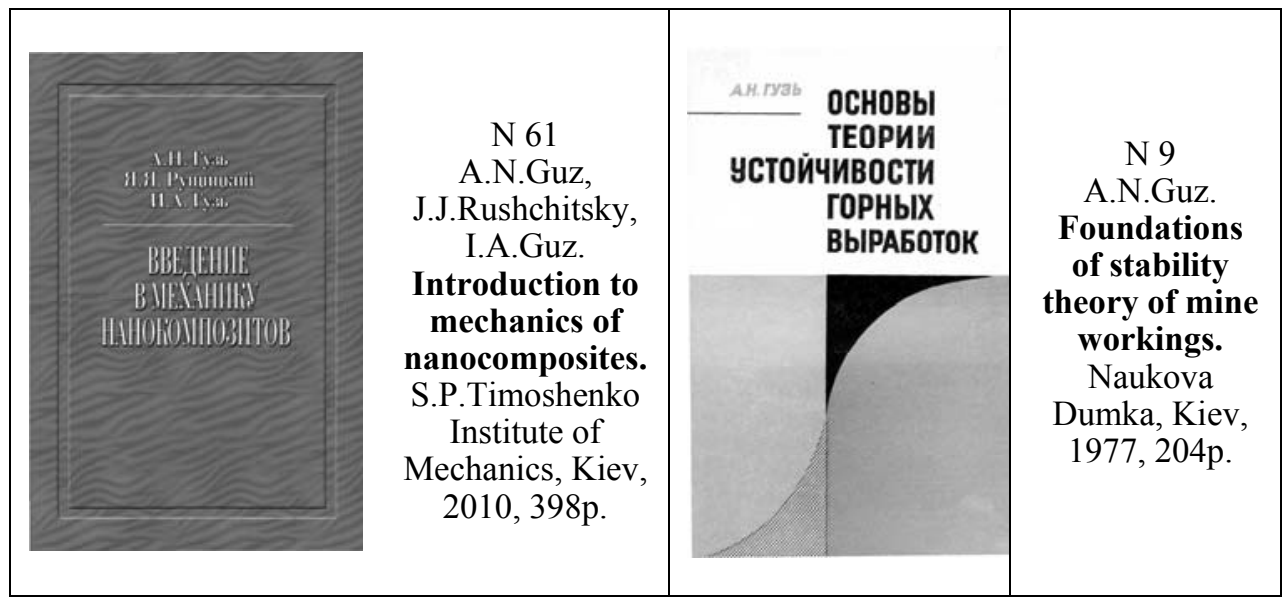

three published solo books on elastic waves propagation in bodies with initial (residual) stresses

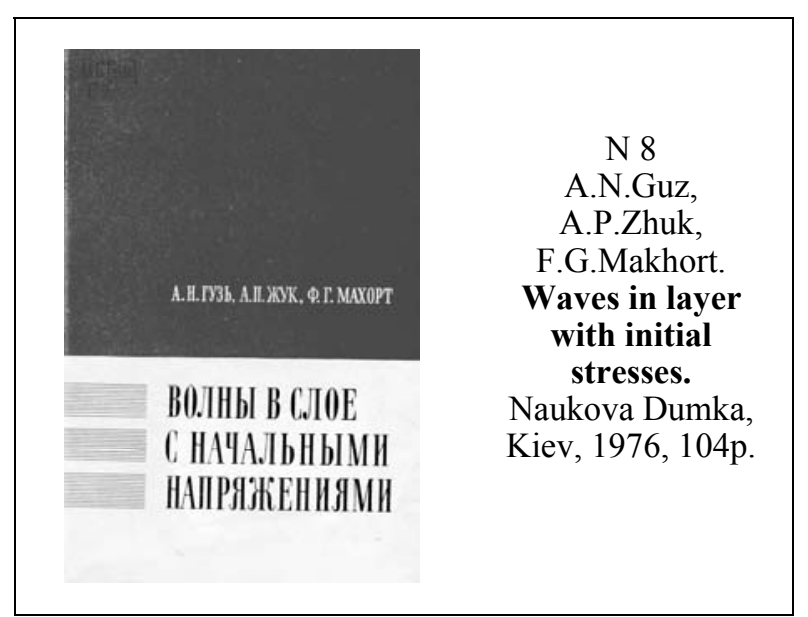




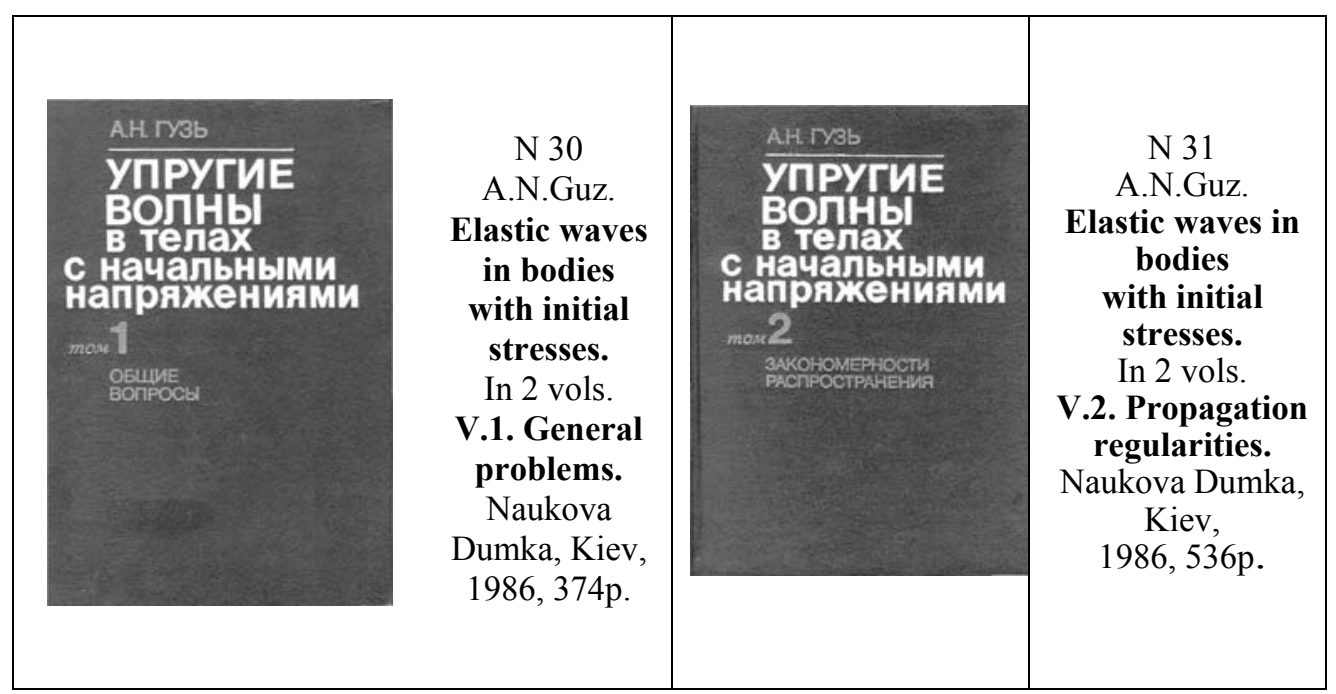

one published solo book on dynamics of compressible viscous fluid

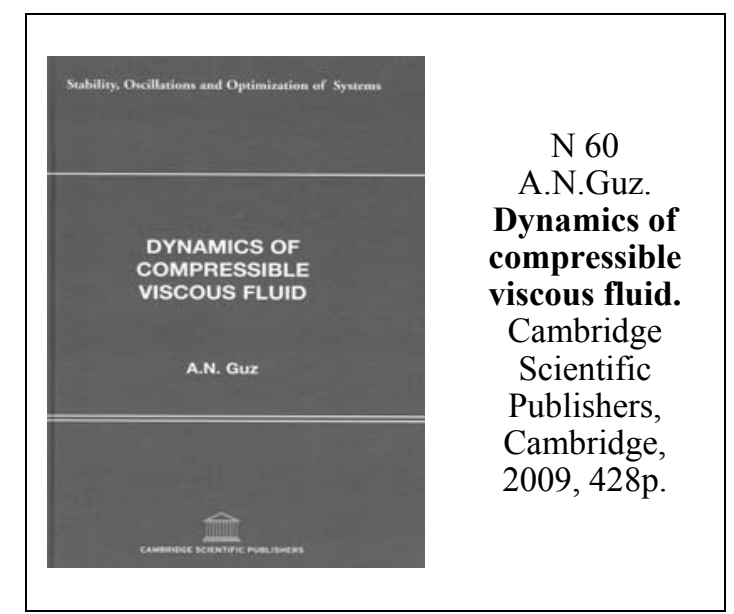

two published solo books on fracture mechanics of materials with initial (residual) stresses

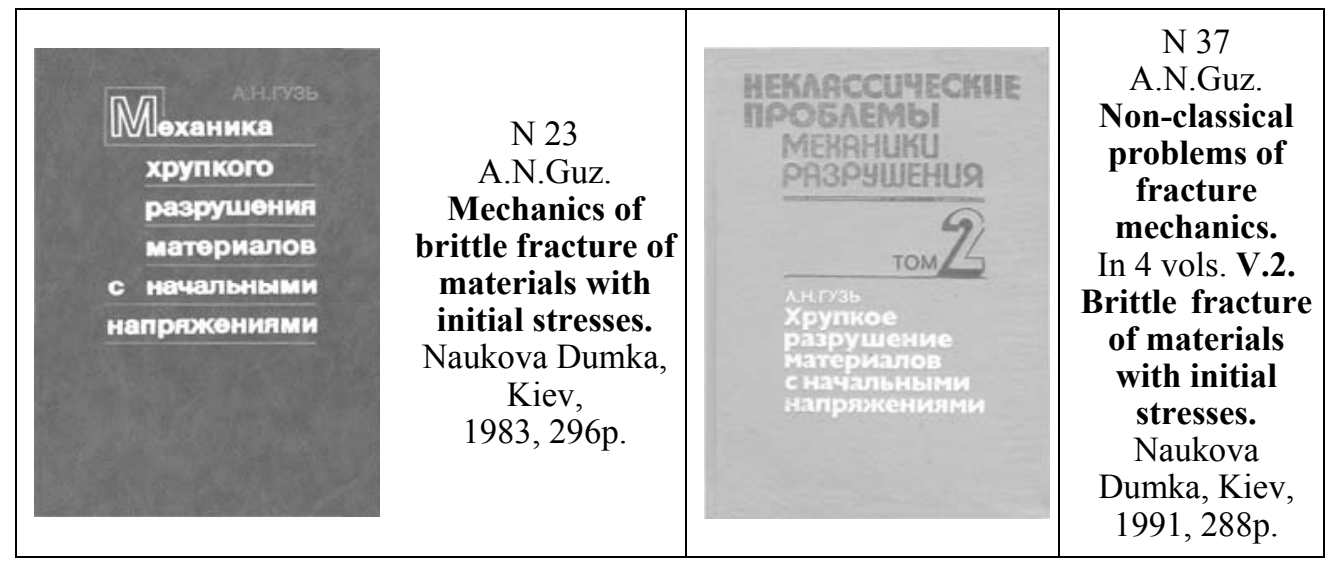


three published solo books on compressible failure of composite materials

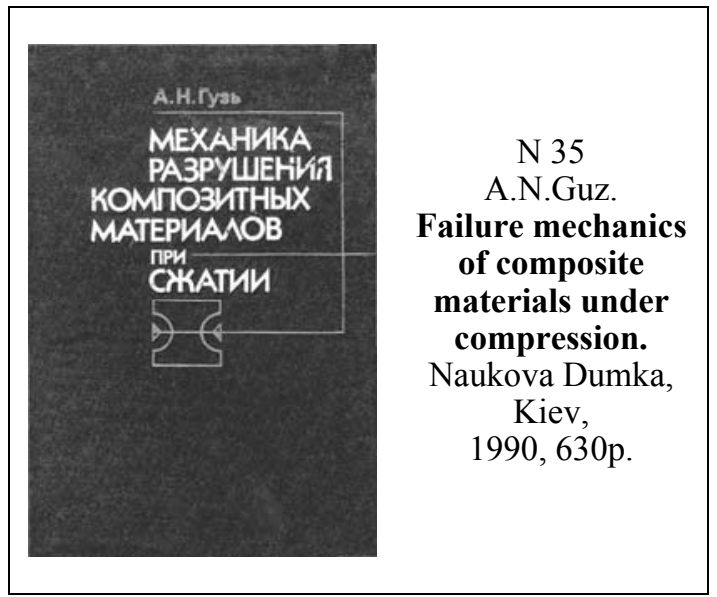

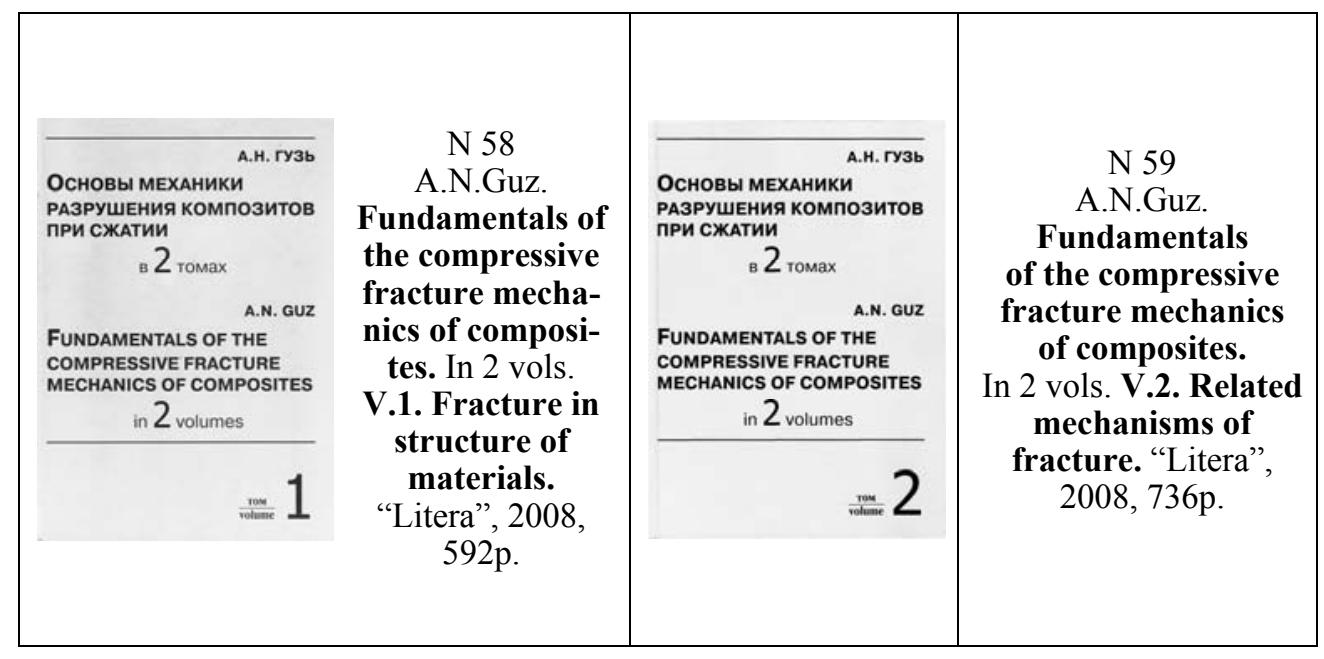

